\title{
AN ANALYSIS OF STUDENTS' ERROR USING PREPOSITION IN NARRATIVE TEXT AT THE THIRD SEMESTER OF ENGLISH EDUCATION STUDY PROGRAM MUHAMMADIYAH UNIVERSITY OF METRO ACADEMIC YEAR 2015/2016
}

\author{
Atika Dwiyanti \\ University of Ahmad Dahlan, Indonesia \\ atikadwiyanti@gmail.com
}

\begin{abstract}
The third semester of English Education Study Program is supposed to have been able to use preposition correctly. The objectives of this research are to find out what kind of error do the students make in using prepositions based on Surface Strategy taxonomy when they write narrative text; to find out how often the students make error in using preposition when they write narrative text; to find out what are the reasons of the students to make error in using preposition when they write narrative text.This research is a qualitative research. The data analyzed are based on descriptive analysis, namely collecting the data, analyse the students error, classifying the students errors, describing errors based on their type, classifying the result of interview.This research was conducted at Muhammadiyah University of Metro. The subject is third semester of English Department academic year 2015/2016 with 32 students as participant. The data were collected from writing test and interview. The result of research showed that the highest percentages of the errors belong to addition type (48\%). The second percentage is misformation type (29\%). Then the third is omission type $(21 \%)$. Next, the last percentage is misordering $(2 \%)$. It means that the most committed errors made by the students is addition. The studenst really often made error in using preposition when they write narrative text and the students made error in using preposition when they write narrative text is the students were confuse in using prepositions and they did not understand how to differentiate them.
\end{abstract}

Keywords: students' error, preposition, narrative text

\section{INTRODUCTION}

Prepositions are short words that introduce information to the readers. This information can include where something takes place, when or why something take place or general descriptive information. When the students will write about narrative text, one of the important thing is the grammar especially how to use preposition well to be the best written. Preposition is a word used before a noun or pronoun to show place, position, or time. So preposition is the important one to be used when someone write a text especially in English.

One of the English skills is writing. Writing error is a mistake to write appropriate with punctuation, spelling, or grammar. The students need to learn writing because it can increase their ability in writing skill, then in writing they can express their feeling and their imagination. Writing is a way to express feelings, ideas, arguments, willingness and thoughts in the form of words in sentences. This language skill is used to communicate from one to another by writing. Some pieces of written work are completely full of mistakes, but even in these cases, overcorrection can have a very demotivating effect. One way of avoiding the 'overcorrection' problem is for teachers to tell their students that for a particular piece of work they are only going to correct mistakes of punctuation, or spelling, or grammar etc. 
There are many kinds of texts are given, the kinds of texts are descriptive, argumentative, persuasive, and narrative. This research will analyse narrative text that written by third semester of Muhammadiyah university of Metro. Then, why the students write and study a narrative text, it is because of narrative text as a story of human experience. Narrative text tells an imaginative story, legend, myth and many other. So that the students arrange easily the composition.

There are common errors of students Muhammadiyah University of Metro especially for third semester in writing. The common errors of writing a narrative text are in sentence pattern in subject, to be, noun, adverb, adjective or preposition. Based on the problem above, the writer will analyze error preposition. Usually most of the students are confused to put preposition like preposition of time or place in sentences, so their sentences are wrong. Many students of Muhammadiyah University are confused to put the right preposition and this is a job for the lecturer to explain clearly about preposition because the use of preposition is necessary, it is to know where the things in the certain place. So, to teach them, the teachers use a text which relates to preposition.

The reseacher conducted the pre survey at Muhammadiyah University of Metro. The reseacher conducted pre survey to find out the students ability in writing narrative and to find out how often do the students make error in using preposition when they write narrative text.

Referring to the background of study above, this research is intended to answer the following questions:

a. What kind of error do the students make in using prepositions based on Surface Strategy taxonomy when they write narrative text?

b. How often do the students make error in using preposition when they write narrative text?

c. What are the reasons of the students to make error in using preposition when they write narrative text?

Based on the formulation of problem on this research is to know and analyze the errors in writing, especially pertaining to use preposition in narrative text. So, the researcher has the objectives:

a. To find out what kind of error do the students make in using prepositions based on Surface Strategy Taxonomy when they write narrative text.

b. To find out how often the studenst make error in using preposition when they write narrative text.

c. To find out what are the reasons of the students to make error in using preposition when they write narrative text.

\section{LITERATURE REVIEW}

a. Concept of Error

Brown (2000:216) states that in process of learning a target language, the learners cannot avoid of making errors. The erroneous of assumption-mistake, misjudgment and miscalculation form an important aspect of learning virtually any skill or acquiring information. Brown (2000: 218) says that the errors can be observed, analyzed, and classified to reveal something of the system operating within the learner, led to a surge of study of learners' errors, called error analysis. Error analysis is used to analyze and classify the learners' error from which the leaners learning problem can be inferred. According to Brown (2007:258) An error is a noticeable deviation from the adult grammar of native speaker, reflecting the interlanguage competence of the learner. 


\section{b. Concept of Analysis}

The second one is Analysis is the process of breaking a complex topic or substance into smaller parts in order to gain a better understanding of it. Analysis is the most established and esteemed forum in which to publish short discussions of topics in philosophy. Analysis maintains a distinctive, concise style and covers a wide range of topics including: philosophical logic and philosophy of language, metaphysics, epistemology, philosophy of mind, moral philosophy, and political philosophy. (http://analysis.oxfordjournals.org/)

c. Concept of Error Analysis

Brown (2007:259) states that error analysis is the fact that learners do make errors and that these errors can be observed, analyzed, and classified to reveal something of the system operating within the learner, led to a surge of study of learner's errors. It implies that error analysis is a procedure including observing, analyzing and classifying the errors on the second language rules and disclosing systems controlled by the learners.

Brown (2000:218) said that error analysis is the study of learner's errors that can be observed, analyzed and classified to reveal something of the system operating within the learner, led to a surge of study of learner's errors.

d. Concept of Preposition

According to Seaton and Mew (2007:132) preposition is a word that connects one thing with another, showing how they are related. Some prepositions tell you about position or place.

e. Concept of Writing

According to Harmer (2007:112) writing is used as an aide-memoire or practice tool to help students practise and work with language they have been studying. Writing is a process of creating, organizing, writing and polishing. In addition writings are organized in a similar way, introduction, development of the main ideas or arguments, conclusion.

f. Concept of Narrative text

According to Clandinin, D.J and Conelly, F.M (2000) states that narrative text is a construct created in a suitable medium (speech, writing, reading, images) that described in a sequence of real or unreal events. I mean that narrative text is an account of event; narrative text is a kind of text that deals with telling about a sequence of event or about something happening to someone.

Narrative is one of the text types that exist in English culture; generally, the purpose of narrative is to entertain and to deal with actual or sensational experience in different ways. This form can both imaginary and factual. Additionally, the most important of this text is that always focuses on the sequences of action or events Derewianka (2000:40).

\section{METHODS}

This study is a Qualitative research which uses error analysis study. Qualitative research is distinguished from quantitative research in that quantitavive research is concerned with frequency while qualitative research is concerned with Abstract characteristics of event. So the researcher concludes that qualitative research is the research which uses description data to be analysed. The writer will use this method to examine of the events or phenomena of student, especially preposition in narrative text.

The object of this research is preposition, prepositions are words that have a relationship with other words in a sentences it is usually comes before noun. 
Preposition is one of part of speech which is covered by grammar, it is one of the material that have been hard for the students especially in university. The subject of this research is the students of Muhammadiyah university of Metro at the third semester academic year 2015/2016. The researcher chooses this subject because the students in this university have studied about preposition in grammar 1 and 2 but they are still make error when they use it in writing narrative text. Then the place of the research is in the Muhammadiyah University of Metro.

In this research the researcher will give test of writing narrative text to the students. Then the researcher will analyse the error that done by the students of using preposition in writing narrative text. After analyse it, the researcher knows the kinds of students' preposition error when they write narrative text. Other instrument that the researcher uses is interview. The researcher will interview the students who get low score when using preposition in narrative text, it is to know what the reasons of the students to make error are.

The researcher will analyse the data by doing:

a. Analyse the Students Error

To analyse the errors, the researcher sees each of students' test that have done.

b. Classifying the Students Error

After analyse the errors, then the researcher classified the errors which preposition that most error made by the students.

c. Describing Errors Based on Their Type

The researcher will make some of tables to classify the kinds of error that made by the students. The errors which have been calculated, then, analyzed or identified into surface strategy taxonomy which is divided into omission, addition, misformation, and misordering.

d. Classifying the Result of Interview

The researcher will classify the result of interview that have done to know the result of interview, the researcher will make a table to make it clear.

\section{FINDINGS AND DISCUSSION}

a. The Types of Error Based on Surface Strategy Taxonomy which often Made by the Students

Based on the result of writing test, the researcher found that most of the students made errors in using preposition on their writing narrative text. From the total errors (48 errors) the highest percentage of errors is belong to addition type (48 \%), for example Cinderella lived with happily. For this sentence "Cinderella lived with happily." The student added 'with' before 'happily'. In this sentence preposition 'with' was not necessary, because the meaning of the sentence was absurd while prepositions 'with' added. The correct sentence should be Cinderella lived happily.

Second was belong to omission type (29\%). For example Step mother snow white ordered guardian. From the example of this sentence, the student omitted ' $o f$ ' before 'snow white'. The correct sentence should be Step mother of snow white ordered guardian.

The third was belong to misformation type $(21 \%)$, for example Step mother snow white ordered guardian. From this sentence, the student omitted 'of' before 'snow white'. The correct sentence should be Step mother of snow white ordered guardian.

The last one is belong to misordering type (2\%). For example. He over climbing a ladder. For those sentences above, the students were wrong in arranging 
the sentences. The student was wrong while put 'over' in the second of the sentence, it should be located after 'climbing' for the correct sentence. Next, before 'climbing' the student should give to be 'was'. The correct sentence should be $\mathrm{He}$ climbing over a ladder.

It shows that the most committed errors made by the students were errors belong to addition type ( $48 \%$ ), and the lowest errors made by the students is errors belong to misordering type (2\%).

b. How Often Do the Students Make Error in Using Preposition when They Write Narrative Text

Based on the analysis of the students' error using preposition in writing narrative text, the researcher also found how often do the students make error in using preposition when they write narrative text from interview the students who got low result in previous writing test. From the data interview, the researcher found that almost all of the students really often make error of using preposition in writing narrative text. It because they were still confused to put the correct preposition in the sentence.

c. The Reasons of the Students' Error in Using Preposition when They Write Narrative Text

After the researcher did the interview to the students, the researcher found some reasons of the students' error in using preposition when they write narrative text, first the students were difficult to memories the words of preposition. Second, they were confused to put the correct prepositions in sentences. They were difficult to differentiate of using preposition. Third, although the students have got material about preposition from their lecturer, they were not master the preposition well. They said that their lecturer have explained about preposition well but they thought that prepositions were hard material to be mastered. Last the most reason of the students' error in using preposition when they write narrative text is the students might think that all prepositions have the same meaning and it will not influence the sentence meaning. The students confuse in using prepositions and they did not understand how to differentiate between the use of some prepositions which have the same meaning in Indonesian and English. For example in the sentence "I see a cat in the table", in this case prepositions of place 'on' substituted by ' $i n$ '. 'In' and 'on' have the same meaning, but actually different in using and function.

\section{CONCLUSION AND SUGGESTION}

5.1 Conclusion of the Research

Based on research objective and analysis of the data from writing test and interview, the researcher concludes:

a. The students of third semester in English Education Study Program Muhammadiyah University of Metro made errors using prepositions in their writing narrative text. The types of error were addition (48 \%), misformation (29\%), omission $(21 \%)$ and misordering $(2 \%)$. Based on the result the researcher found that the most committed errors made by the student in using prepositions was addition (48\%).

b. Based on the analysis of the students' error using preposition in writing narrative text, the researcher also found how often do the students made error in using preposition when they write narrative text from interview the students who got low result in previous writing test. From the data interview, the researcher found that almost all of the students really often made error using 
preposition in writing narrative text. It because they were still confused to put the correct preposition in sentence.

c. The reasons of the students made error using preposition when they write narrative text were first the students were difficult to memories the words of preposition. Second, they were confused to put the correct prepositions in sentences. They were difficult to differentiate of using preposition. Third, although the students have got material about preposition from their lecturer, they were not master the preposition well. They said that their lecturer have explained about preposition well but they thought that prepositions were hard material to be mastered. Last the most reason of the students' error in using preposition when they write narrative text is the students might think that all prepositions have the same meaning and it will not influence the sentence meaning. The students confuse in using prepositions and they did not understand how to differentiate between the use of some prepositions which have the same meaning in Indonesian and English.

5.2 Suggestions of the Research

Based on the conclusion of the research, the writer proposes some suggestions as follows:

a. The lecturer should explain as clear as possible about the material of prepositions not only meaning and the example but also the usage. So the students will not misunderstand with the prepositions which has the same meaning in Indonesian.

b. The lecturer should know the classification and the cause of students' errors, so she/he would know what and how to correct the students' errors.

c. The lecturer should pay attention to the students' errors in order to prevent or to minimize those errors. The lecturer must check students' writing and help them to correct it.

d. The lecturer should find the appropriate technique in teaching prepositions in order to make the students comprehend it easily. For example, the lecturer uses picture or video about preposition as a media in teaching prepositions.

e. The students have to be able to master preposition because when the students will write narrative text, they should put the correct prepositions to make right sentences. For that reason, the students have to master all of prepositions to write narrative text well.

f. The future researcher should knows the information about prepositions. Therefore, when the researcher wants to do the similar research the future researcher can read this thesis as reference.

\section{REFERENCES}

Brown, H. Douglas. 2000. Principles of Language Learning and Teaching. Englewood Cliffs: Addison Wesley Longman, Inc.

Brown, H. D.2000. Principles of Language Learning and Teaching (4th. Ed.). White Plains. New York: Pearson Education.

Brown, H. Douglas. 2007. Principle of Language Learning and Teaching, 5th edition. New York: Pearson Education, Inc.

Clandinin, D.J and Connelly, F.M. 2000. Narrative text.

Derewianka. 2000. Exploring How Text Work. Teaching Association

Harmer, J. 2007. How to Teach English. England: Pearson Education.

Seaton, Anne \& Mew, Y. H.2007. Basic English Grammar. The United States of America: Saddleback Educational. 